\title{
DETERMINATION MINING ZONE OF NON-METAL MINERAL AND ROCK BASED ON SEDIMENT INFLOW AND OUTFLOW IN THE BODRI RIVER KENDAL REGENCY
}

\author{
Reynold Bagus Riyanto ${ }^{1}$, Tri Hardono ${ }^{2}$, Ari Sentani ${ }^{2 *}$ \\ ${ }^{I}$ The Department Master of Civil Engineering, Faculty of Engineering, Sultan Agung Islamic University, Jl. \\ Raya Kaligawe Km. 4 Semarang, 50112, Indonesia \\ ${ }^{2}$ Lecturer of Civil Engineering Master, Faculty of Engineering, Sultan Agung Islamic University, Jl. Raya \\ Kaligawe Km. 4 Semarang, 50112, Indonesia \\ *Corresponding author: arisentani@unissula.ac.id
}

\begin{abstract}
Local traditional mining in the Bodri River Kendal regency increasingly concerned, this is of course if left unchecked will damage the river body, river channel, causing landslides, can even disrupt the stability of water buildings such as weirs and bridges. The purpose of this research is as an effort to Determine Non-Metal and Rock Mineral Mining Zonation Based on the Inflow and Outflow of Sediment in Bodri River of Kendal Regency, to obtain the areas which are allowed to be mined and the mining volume. This research is descriptive qualitative by doing direct observation, interview and documentation. Descriptive method is a method used to examine the status of human groups, an object, a condition and a system of thought and events that will occur. The purpose of this study is to create an explorative, systematics, factual and accurate facts on the specific case. The research results are sediment inflow to the Bodri river is 103.327,40 ton/year, whereas the outflow is 379.459 .46 ton/year, which mean the river morphology has serious problem caused by the mining activity.
\end{abstract}

Keywords: Zoning, Mining, Non-Metal Material and Rocks, Sediment

\section{INTRODUCTION}

Bodri Watershed is part of the Bodri Jragung Watershed Management Unit. The area of the Bodri watershed covers an area of 65,248.53 ha. Bodri Watershed has a length of 189.22 $\mathrm{Km}$. The main river of the Bodri watershed is Kali Bodri with a river length of $80.73 \mathrm{~km}$. Lately, mining activities in the Bodri river have become increasingly alarming, of course if it left unchecked it will damage the river body, river flow, cause landslides, and even disrupt the stability of water buildings such as weirs and bridges. Mining is traditionally carried out by the community near the river in the dry season and carried out by entrepreneurs using a backhoe, either licensed or not licensed.

Based on the explanation above, many non-metallic minerals and rocks (sirtu) in Kendal Regency are problematic, not only those who are not licensed, but also those who are licensed. The environment around mining non-metallic minerals and rocks (sirtu) becomes severely damaged and the ecosystem dies. Many miners do not take care of the environment 
after mining (reclamation). Increasingly, the mining marks were dry without trees and the roads in the valley were damaged. This condition is very disturbing to the local communities.

\subsection{Watershed}

The watershed is a land area which is topographically limited by the ridges of the mountains that hold and store rainwater to then channel it to the sea through the main river (Asdak, 2002). The land area is called the catchment area, which is an ecosystem with the main elements consisting of natural resources (land, water, and vegetation) and human resources as users of natural resources.

\subsection{Erosion}

Hydrological processes, direct or indirect, have related to erosion, sediment transport and sediment deposition in the downstream area. Land use and watershed management practices changes also affect erosion, sedimentation, and in turn, will affect water quality (Asdak, 2002).

The USLE (Universal Soil Loss Equation) model is the most commonly used method. The USLE method can be used to predict the amount of erosion for various conditions of land use and different climatic conditions. USLE allows planners to predict the average erosion rate of a particular land at a slope with certain rainfall patterns for each soil type and the application of land management (land conservation measures). USLE is designed to predict long-term erosion of sheet erosion and groove erosion under certain conditions. These equations can also predict erosion on non-agricultural lands, but cannot predict sedimentation and do not account for sediment yields from trench erosion, river banks and riverbed (Suripin, 2004). The USLE equation is as follows:

$\mathrm{A}=\mathrm{R} \times \mathrm{K} \times \mathrm{LS} \times \mathrm{C} \times \mathrm{P}$

With :

A = The amount of land lost on average each year (tons / ha / year)

$\mathrm{R}=$ Rainfall erosion index (rain erosivity) $(\mathrm{KJ} / \mathrm{ha})$

$\mathrm{K}=$ Soil sensitivity index for erosion (soil erodibility)

LS = The length factor (L) and the steep (S) slope

$\mathrm{C}=$ Plant factors (vegetation)

$\mathrm{P} \quad=$ Factor for Erosion Prevention Effort 


\subsection{Sedimentation}

Sedimentation is defined as the displacement and deposition of soil erosion, specifically as a result of the acceleration of sheet erosion and groove erosion (White. 1987, in Budi Indra, 1999). Sediments generally settle at the bottom of the foothills, in flooded areas, in waterways, rivers and reservoirs (Asdak, 2002). From the sedimentation process, only a portion of the sediment flow in the river is transported out of the watershed, while others settle in certain locations from the river.

Sediment yield is the amount of sediment which derive from erosion both in the river or in the catchment area which is measured at a certain time and place period. Sediment yield is usually obtained from measurements of dissolved sediment in the river (suspended load).

\subsubsection{Sediment Transport Monitoring}

Sediment monitoring is a major factor in the management of a watershed because it can give a more real and realistic picture and estimate of the critical picture of a watershed compared to other methods that move based on assumptions and from inadequate watershed characteristics data. Sediment transport (Sediment transport) can be divided into two ways, namely:

1. Suspended load, where very small sedimentary particles move to float along the flow of water

2. Basic transport (bed load), where the movement of particles is not far from the riverbed and moves in a shift, sliding or jumping

While depend on the origin of the sediment particles can be divided into two, which are:

1. Wash load, which is part of the sediment transport load consisting of very fine grains compared to the river bottom and usually comes from soil erosion.

2. River material load (bed material load), is part of the sediment transport load consisting of grains originated from the river bed

\subsubsection{Sediment Delivery Ratio (SDR)}

Soils and parts of land that are transported from places commonly called sediments. Sediment material from mirror erosion moves a short distance before being deposited. Only a portion or even a small portion of eroded sediment material (DAS) reaches the basin outlet, 
and is carried out of the catchment area or watershed. The result of erosion that reaches the outlet is usually called sediment yil (Suripin, 2004).

The ratio of the amount of sediment that is really carried by the river from an area to the amount of soil eroded from the area is called the Sediment Release Ratio (NPS) or SDR. In calculating SDR the formula used is (DPU Dirjen Pengairan, 1999):

$$
\mathrm{SDR}=\mathrm{s} \times \frac{\left(1-0.8683\left(\mathrm{~A}^{-0.2018}\right)\right)}{2(\mathrm{~S}+50 \times \mathrm{n})}+0.8683\left(\mathrm{~A}^{-0.2018}\right)
$$

Which :

$\mathrm{SDR}=$ sediment release ratio, the value is $0<\mathrm{SDR}<1$

A $=$ the widht of watershed area (ha)

$\mathrm{S} \quad=$ the tillt of surface watershed slope $(\%)$

$\mathrm{n} \quad=$ manning roughness coefficient

Furthermore, for the calculation of the sedimentation rate can be calculated by the equation as follows:

$\mathrm{Qs}=\mathrm{SDR} \times \mathrm{A}$

with :

Qs = sedimentation rate (ton / yr)

SDR = sediment release ratio

A $\quad=$ erosion rate $($ ton $/ \mathrm{yr})$

\subsection{Regulations Relating to Watershed Management}

In planning the main activity which is the impact, one way to minimize the impact of an activity is complementary to laws and regulations. These regulations include:

1. Government Regulation of the Republic of Indonesia No. 38 of 2011, regarding commensurate rivers.

2. Regional Regulation of Central Java Province No. 9 of 2013, about commensurate lines.

3. Decision of Director General of Irrigation No. 176 / KPTS / A / 1987 concerning Implementation Guidelines on River Safeguards in Relations with Mining Group C.

\subsection{Determination of Zoning Criteria Based on Sediment Inflow and Outflow}

To maintain the morphology of the river, the ratio between the inflow (sedimentation in the river) and the outflow (mining activity) of the sediment must be greater than 1.5 times, 
which means that the sediment outflow activity for 1 year must be 1.5 times smaller than the sediment inflow capability.

\subsection{Determination of Non-Metallic Mineral and Rock Mineral Zoning Based on Sediment Inflow and Outflow}

From the rules relating to watershed management and zoning criteria based on sediment inflow and outflow, the zoning arranged, is proposed to be classified into two categories, which are:

1. Zone A (mining is not allowed)

2. Zone B (mining may be carried out on one cross section of the river).

\section{RESULTS AND DISCUSSION}

Based on the results of the spatial analysis in determining the boundaries of the Bodri watershed, it was found that the Bodri watershed area was divided into 9 sub-watersheds, with the following characteristics:

Table 1. Characteristics of the Bodri Sub-watershed

\begin{tabular}{|c|c|c|c|c|}
\hline No & $\begin{array}{c}\text { Sub - } \\
\text { Watershed }\end{array}$ & $\begin{array}{l}\text { Width } \\
\text { (Ha) }\end{array}$ & $\begin{array}{c}\text { Slopeof } \\
\text { Land } \\
(\%)\end{array}$ & $\begin{array}{c}\text { Long } \\
\text { Slope } \\
\text { (m) }\end{array}$ \\
\hline 1 & 1 & 7492.45 & 7.29 & 39651.97 \\
\hline 2 & 2 & 525.40 & 17.64 & 4259.02 \\
\hline 3 & 3 & 262.70 & 14.52 & 3164.85 \\
\hline 4 & 4 & 8929.16 & 15.55 & 37336.09 \\
\hline 5 & 5 & 1344.29 & 14.26 & 9848.12 \\
\hline 6 & 6 & 7246.01 & 19.39 & 19862.66 \\
\hline 7 & 7 & 12080.68 & 22.11 & 22045.00 \\
\hline 8 & 8 & 8728.93 & 16.95 & 31121.35 \\
\hline \multirow[t]{2}{*}{9} & 9 & 9916.63 & 22.44 & 32292.15 \\
\hline & Total & 56526.25 & & \\
\hline
\end{tabular}




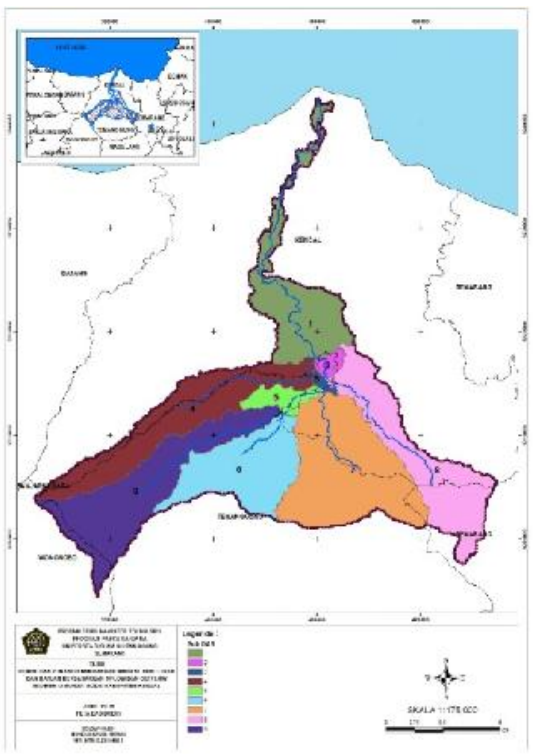

Figure 1. Bodri Watershed Map

\subsection{Factors of Rainy Erosion (R)}

By using the isohyet WS Bodri Kuto map, the Bodri watershed shows the following results:

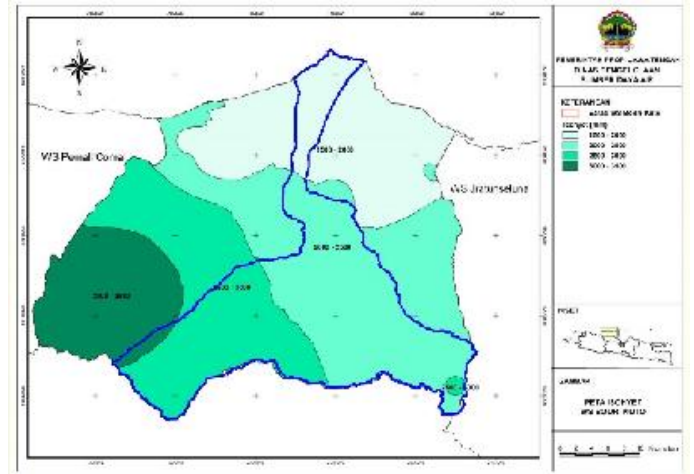

Figure 2. Isohyet Map of Bodri Watershed

P Average $\quad=2385,90 \mathrm{~mm}$

Factors of Rainy Erosion (R)

$\mathrm{R}=(0.41 \times \mathrm{H}) \times 1.09$

$\mathrm{R}=(0.41 \times 2385.9) \times 1.09$

$\mathrm{R}=1817.92 \mathrm{~mm} / \mathrm{th}$

$\mathrm{R}=181.79 \mathrm{~cm} / \mathrm{th}$ 


\subsection{Soil Efficiency Factor $(\mathbf{K})$}

The type of soil according to FAO has its own erodibility factor values as can be seen in the following table:

Table 2. Erodibility of each type of Soil

\begin{tabular}{clc}
\hline No. & \multicolumn{1}{c}{ Types of Soil } & K) \\
\hline 1 & Latosol coklat kemerahan dan litosol & 0,43 \\
\hline 2 & Latosol kuning kemerahan dan litosol & 0,36 \\
\hline 3 & Komplek mediteran dan litosol & 0,46 \\
\hline 4 & Latosol kuning kemerahan & 0,56 \\
\hline 5 & Grumusol & 0,20 \\
\hline 6 & Aluvial & 0,47 \\
\hline 7 & Regusol & 0,40 \\
\hline Source: & Arsyad,1989 dan Asdak, 1995
\end{tabular}

\subsection{Slope Length Factor (L) And Slope Gradient (S)}

Slope grade is calculated based on slope length and slope length data obtained from spatial analysis of topographic maps (contours) of the Map of Indonesian Earth. slope factors are calculated based on the following equation (Utomo, 1994).

$$
L S=\sqrt{\left(\frac{L}{100}\right) \times\left(0.136+(0.097 \times S)+\left(0.0139 \times S^{2}\right)\right)}
$$

Which are :

$$
\begin{array}{ll}
\mathrm{LS} & =\text { Slope length and slope factor } \\
\mathrm{L} & =\text { Slope length }(\mathrm{m}) \\
\mathrm{S} & =\text { Slope Gradient }
\end{array}
$$

\subsection{Land Use Factor C, and Land Management (P)}

The factors of land use and land management depend on the Bodri watershed land use map. The following are some of the values of land management and land use.

Table 3. CP Value

\begin{tabular}{clcc}
\hline No & \multicolumn{1}{c}{ Land Use } & C & P \\
\hline 1 & Fresh water & 0 & 1 \\
\hline 2 & Shrubs/ Bushes & 0.4 & 1 \\
\hline 3 & The Pond & 0 & 1 \\
\hline 4 & Building & 1 & 1 \\
\hline 5 & Forest & 0.01 & 1 \\
\hline 6 & Garden & 0.2 & 1 \\
\hline 7 & Settlemant & 1 & 1 \\
\hline
\end{tabular}




\begin{tabular}{clcc}
\hline No & \multicolumn{1}{c}{ Land Use } & C & P \\
\hline 8 & Grass & 0.02 & 1 \\
\hline 9 & Irrigated Rice Fields & 0.88 & 1 \\
\hline 10 & Rainfed Raice Fields & 0.6 & 1 \\
\hline 11 & Field Land & 0.63 & 1 \\
\hline
\end{tabular}

\section{ANALYSIS OF EROSION RATE}

Based on the calculation results using the USLE method, the amount of eroded land in the Bodri watershed is $37,922.67$ tons / ha / year or 863,095.35 tons / year. With erosion hazard class as follows:

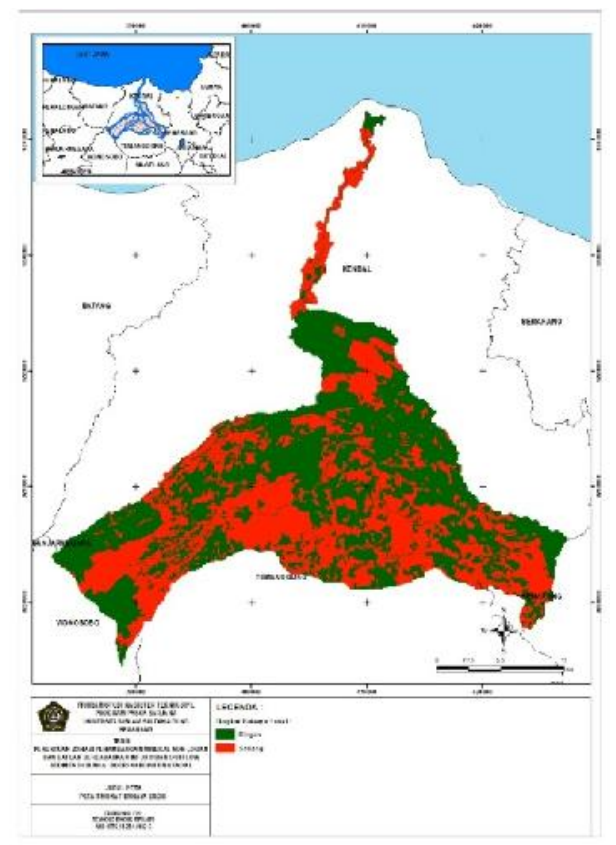

Figure 3. Erosion hazard map

\subsection{Analysis of Sedimentation Rate}

The ratio of the amount of sediment that is really carried by the river from an area to the amount of soil eroded from the area is called the Sediment Release Ratio (NPS) or SDR (Sediment Delivery Ratio). In calculating SDR the formula used is (Saygın et al, 2014).

$$
\begin{aligned}
& \mathrm{SDR}=\mathrm{s} \times \frac{\left(1-0.8683\left(\mathrm{~A}^{-0.2018}\right)\right)}{2(\mathrm{~S}+50 \times \mathrm{n})}+0.8683\left(\mathrm{~A}^{-0.2018}\right) \\
& \mathrm{SDR}=0.176 \times \frac{\left(1-0.8683\left(56524^{-0.2018}\right)\right)}{2(0.1762+50 \times 0.025)}+0.8683\left(56524^{-0.2018}\right) \\
& \mathrm{SDR}=0.151
\end{aligned}
$$


Calculation of sedimentation rate can be calculated with the following equation (DPU Dirjen Pengairan, 1999):

$$
\begin{aligned}
& \mathrm{O}_{\text {sedimentation }}=\mathrm{SDR} \times \mathrm{A} \quad \ldots \ldots \ldots \ldots \ldots \ldots \ldots \\
& \mathrm{O}_{\text {sedimentation }}=0.151 \times 863,095.35 \mathrm{ton} / \mathrm{yr} \\
& \mathrm{O}_{\text {sedimentation }}=130,327.40 \mathrm{ton} / \mathrm{yr}
\end{aligned}
$$

With :

Qs $\quad=$ sedimentation rate $($ ton / yr)

SDR = sediment release ratio

A $\quad=$ erosion rate $($ ton $/ \mathrm{yr})$

\subsection{Sedimentation in the Field}

The calculation of sediment in this field is carried out for the calibration process with calculation results. From the laboratory tests, measurements of the Bodri river flyover sediment concentration of sediment (Ci) were $1433.33 \mathrm{mg} / \mathrm{lt}$ with an average river discharge (Qw) of $2.1 \mathrm{~m} 3 / \mathrm{s}$ so:

$$
\begin{aligned}
& \mathrm{Q}_{\text {suspended load }}=0.0864 \times \mathrm{Ci} \times \mathrm{Qw} \ldots \ldots \ldots \ldots \ldots \ldots \ldots \ldots \ldots \\
& \mathrm{Q}_{\text {suspended load }}=0.0864 \times 1,433.33 \mathrm{mg} / \mathrm{lt} \times 2.1 \mathrm{~m}^{3} / \mathrm{dt} \\
& \mathrm{Q}_{\text {suspended load }}=260.06 \mathrm{ton} / \mathrm{day} \\
& \mathrm{Q}_{\text {suspended load }}=94,923.47 \mathrm{ton} / \mathrm{yr}
\end{aligned}
$$

From the results of the calculation of suspended load discharge for one year, the results obtained were 94,923.47 tons / year. From these results it can be calculated the amount of the discharge bed load $(\mathrm{Qb})$ and the total load, which are:

Debit $_{\text {bed load }}(\mathrm{Qb})=30 \% \times \mathrm{Q}_{\text {suspended load }}$

Debit bed load $_{\text {(Qb) }}=30 \% \times 94,923.47$

Debit bed load $(\mathrm{Qb})=28,477.04$ ton/yr

Debit total load $=\mathrm{Q}_{\text {sus load }}+\mathrm{Q}_{\text {bed }}$

Debit $_{\text {total load }}=94,923.47+28,477.04$

Debit total load $=123,400.51$ ton/yr

\subsection{Calibration and Verification}

Calibration and verification is needed to check the results of calculations with data in the field. the volume error (VE) is determined from $0 \%$ to $20 \%$.

Qsim $($ USLE $)=130.327,40$ tons $/$ year 
Field data $=123.400,51$ tons $/$ year

$$
\begin{aligned}
\mathrm{VE} & =\left|\frac{\sum_{\mathrm{i}=1}^{\mathrm{N}} \mathrm{Qdata}-\sum_{\mathrm{i}=1}^{\mathrm{N}} \mathrm{Qsim}}{\sum_{\mathrm{i}=1}^{\mathrm{N}} \text { Qdata }}\right| . \\
\mathrm{VE} & =\left|\frac{123,400.51-130,400.4}{123,400.51}\right| \\
\mathrm{VE} & =0.0561 \\
\mathrm{VE} & =5.61 \%
\end{aligned}
$$

From the results of the calibration and verification analysis above, it can be concluded that the method of calculating sediment transport potential using the USLE method has a value of volume error (VE) of 5.61\% so that the calculation can be used in further analysis.

\subsection{Current Mining Volume}

From the inventory survey results, there are 14 mining locations with 9 locations currently in operation, both licensed and unlicensed, with an average of 10 trucks / locations per day with a truck capacity of $6.00 \mathrm{~m} 3$. With operations on average 5 days in 1 week.

With these conditions can be calculated the volume of excavation of non-metallic

\begin{tabular}{|c|c|c|c|c|c|c|c|c|}
\hline \multirow{2}{*}{$\begin{array}{l}\text { Sub } \\
\text { DAS }\end{array}$} & \multirow{2}{*}{$\begin{array}{c}\text { Jumlah } \\
\text { Penambang }\end{array}$} & \multicolumn{5}{|c|}{ Volume Penambangan (outflow) } & \multirow{2}{*}{$\begin{array}{c}\text { Inflow } \\
\text { Sedimen } \\
\text { (ton/tahun) }\end{array}$} & \multirow{2}{*}{$\begin{array}{l}\text { Komulatif } \\
\text { (ton/tahun) }\end{array}$} \\
\hline & & $\begin{array}{c}\text { Truc/har } \\
\text { i }\end{array}$ & $\begin{array}{l}\text { VolTruc } \\
\text { k (m3) }\end{array}$ & m3/hari & $\mathrm{m} 3 /$ thn & ton/thn & & \\
\hline 1 & 0 & 0 & 6 & 0 & 0 & - & 130327.398 & $130,327.40$ \\
\hline 1 & 0 & 0 & 6 & 0 & 0 & - & $130,327.40$ & $130,327.40$ \\
\hline 1 & 1 & 10 & 6 & 60 & 15600 & $42,162.16$ & $130,327.40$ & $88,165.24$ \\
\hline 1 & 0 & 0 & 6 & 0 & 0 & - & $130,327.40$ & $88,165.24$ \\
\hline 1 & 1 & 10 & 6 & 60 & 15600 & $42,162.16$ & $130,327.40$ & $46,003.07$ \\
\hline 1 & 1 & 10 & 6 & 60 & 15600 & $42,162.16$ & $130,327.40$ & $3,840.91$ \\
\hline 1 & 2 & 10 & 6 & 120 & 31200 & $84,324.32$ & $130,327.40$ & $(80,483.41)$ \\
\hline 1 & 1 & 10 & 6 & 60 & 15600 & $42,162.16$ & $130,327.40$ & $(122,645.58)$ \\
\hline 1 & 1 & 10 & 6 & 60 & 15600 & $42,162.16$ & $130,327.40$ & $(164,807.74)$ \\
\hline 1 & 1 & 10 & 6 & 60 & 15600 & $42,162.16$ & $130,327.40$ & $(206,969.90)$ \\
\hline 2 & 1 & 10 & 6 & 60 & 15600 & $42,162.16$ & $96,497.10$ & $(249,132.06)$ \\
\hline 2 & 0 & 0 & 6 & 0 & 0 & - & $96,497.10$ & $(249,132.06)$ \\
\hline JML & 9 & & & & 140.400 .00 & 379.459 .46 & & \\
\hline
\end{tabular}
minerals mined in 1 year with the specific gravity of the sediment on the Bodri river an average of $2.67 \mathrm{gr} / \mathrm{cm} 3$ is equal to:

\section{Table 4. Sediment Volume outflow}

Source : Hasil analisa dan perhitungan, Tahun 2018

From the results of the calculation, the material mining in the Bodri river exceeds the existing sediment potential (inflow) of 130,327.40 tons / year which causes the Bodri river morphology to be disrupted, so that there needs to be regulation in mining, one of which is mining zoning. 


\subsection{Mine Zoning Materials}

Based on the analyzes above and results of spatial map processing,zoning of nonmetallic mineral and rock mining based on inflow and sediment outflow on the Bodri river can be seen in Figure 5.

\section{CONCLUSION}

1. The existing condition of the Bodri River has been degraded due to excessive and arbitrary mining of non-metallic minerals and rocks, which can damage the morphology of the river and also the water structures on the Bodri river.

2. The erosion rate in the Bodri watershed based on analysis using the USLE method is $37,922.67$ tons / ha / year or 863,095.35 tons / year with an erosion hazard classification between mild to moderate.

3. Sedimentation rate in the Bodri watershed is 130,327.40 tons / year and the current mining volume (outflow) is $379,459.46$ tons / year.

4. Criteria for determining zoning are based on technical and non-technical aspects. Technical aspects in terms of hydrological aspects (erosion and sedimentation), morphology, topography and availability of non-metallic mineral and rock excavation materials, while non-technical aspects are viewed from land use and building locations around the Bodri river.

5. From the criteria for determining the zoning, mining zones for mining non-metallic minerals and rocks are classified into 2 zones, which are Zone A (zones not to be mined) and zone B (Zones may be mined).

6. The length of the river including Zone A is $27.87 \mathrm{~km}$ while Zone $\mathrm{B}$ is $13.83 \mathrm{Km}$.

\section{REFERENCES}

Agustian, Hendra. 2006. "Kajian Erosi dan Usaha Konservasi pada Sub DAS Cihaur Propinsi Jawa Tengah". Skripsi tidak diterbitkan. Malang : Jurusan Teknik Pengairan.

Arsyad, Sitanala. 2000. Konservasi Tanah dan Air. Bogor : IPB Press.

Asdak, Chay. 2002. Hidrologi dan Pengelolaan Daerah Aliran Sungai. Yogyakarta : Gajah Mada University Press.

Hardjowigeno, Sarwono. 2003. Ilmu Tanah. Jakarta : CV Akademika Pressindo.

Utomo, Wani, Hadi. 1994. Erosi dan Konservasi Tanah. Malang : IKIP Malang.

Harto, Sri. 1993. Analisis Hidrologi. Jakarta : PT Pradnya Paramita. 
Prahasta, Eddy. 2005. Sistem Informasi Geografis : Tutorial ArcView. Bandung : Informatika. Prahasta, Eddy. 2005. Konsep-konsep Dasar Sistem Informasi Geografis. Bandung : Infromatika.

Suripin. 2004. Pelestarian Sumber Daya Tanah dan Air. Yogyakarta : Andi.

Peraturan Menteri Lingkungan Hidup dan Kehutanan Republik Indonesia. No. P.89/MENLHK/SETJEN/KUM. 1/11/2016

Priyantoro, Dwi. 1987. Teknik Pengangkutan Sedimen. Malang : Universitas Brawijaya.

Saygın, S.D., Ozcan, S.U., Basaran, M., Timur, O.B., Dolarslan, M., Yılman, F.E., \& Erpul, G. 2014. The Combined RUSLE/SDR Approach Integrated with GIS and Geostatistics to Estimate Annual SedimentFlux Rates in the Semi-Arid Catchment, Turkey. Journal of Environment Earth Science, 71, 1605-1618, https://link.springer.com/content/pdf/10.1007\%2Fs12665-013-2565-y.pdf 


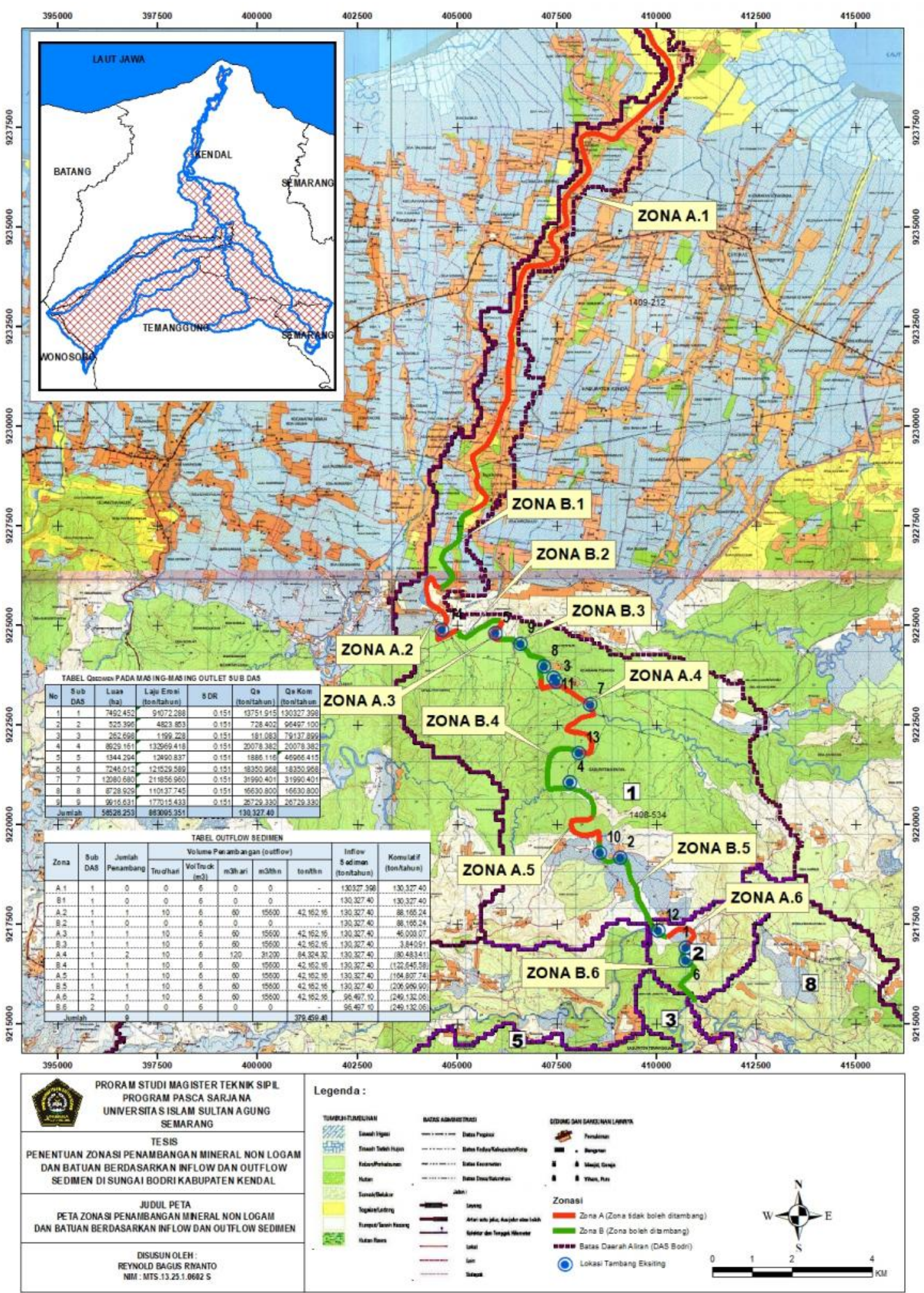

Figure 4. Zoning Map of Mining Non-metal Mineral and Rocks in the Bodri River based on Sediment Inflow and Outflow 